Click www.researchjournal.co.in/online/subdetail.html to purchase.

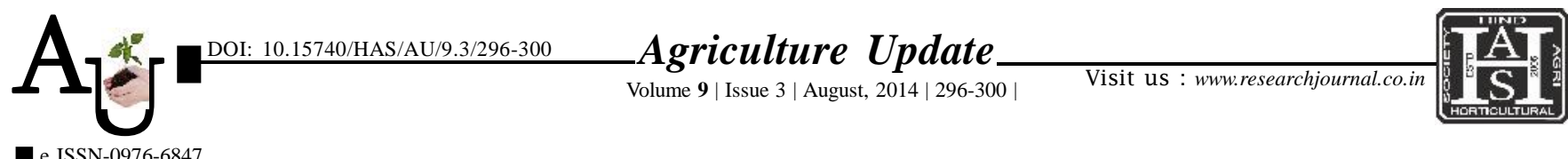

\title{
Research Article Critical analysis of peasantry modernization in agriculture under integrated tribal development project
}

\author{
MUKESH R. PATEL, J. K. PATEL AND S. A. SIPAI
}

Article Chronicle: Summary : The result revealed that majority of the tribal peasants had medium level of overall modernization.

Received :

11.04.2014;

Revised :

24.05.2014;

Accepted :

10.06.2014

\section{KeY WoRds:}

\section{Peasantry}

modernization,

Analysis,

Independent

variables
The independent variables viz., education, size of land holding, farm power, organizational participation, annual income, mass media exposure, change agency contact, level of educational aspiration of their son, economic motivation, cosmopoliteness, risk orientation, scientific orientation and attitude toward Integrated Tribal Development Project of the respondents had positive and significant correlation with their level of overall modernization and only age of the respondents found to be negatively and significantly correlated with their overall modernization. Seven variables viz., annual income, economic motivation, social participation, scientific orientation, education, cosmopoliteness and organizational participation to gathered contributed 89.90 per cent variation to the extent of overall modernization and annual income was the key variable in exerting considerable direct and subsequent indirect effect and cosmopoliteness had maximum positive indirect effect.

How to cite this article : Patel, Mukesh R., Patel, J.K. and Sipai, S.A. (2014). Critical analysis of peasantry modernization in agriculture under integrated tribal development project. Agric. Update, 9(3): 296-300.
Author for correspondence :

\section{S.A.SIPAI}

Department of

Extension Education,

B.A.College of

Agriculture, Anand

Agricultural University,

ANAND (GUJARAT) INDIA

Email:pathansalman29@

yahoo.com

See end of the article for

authors' affiliations 